J. Clin. Chem. Clin. Biochem.

Vol. 21, 1983 pp. 181-184

\title{
Thiopental Monitoring by Gas-Chromatography
}

\author{
By W. R. Külpmann, R. Fitzlaff \\ Technical assistance: K. Petry and L. Lütke-Holz \\ Institut für Klinische Chemie,
}

A. Spring and H. Dietz

Neurochirurgische Klinik, Medizinische Hochschule Hannover

(Received March 25/August 24, 1982)

Summary: A gaschromatographic method is presented for the determination of thiopental (and of its metabolite pentobarbital) in cases of severe head injuries treated by induction of therapeutic barbiturate coma. To $1 \mathrm{ml}$ serum the internal standard and saturated ammonium sulphate solution are added. The mixture is extracted by chloroform and the concentrated organic phase is injected into the gaschromatograph (stationary phase: SP 2510 DA). Imprecision from day to day: Coefficient of variation $7.7 \%$; recovery $97 \%$. The specificity was checked by comparison with the retention time of more than 80 drugs. One determination is accomplished within 1 hour.

Uberwachung der Thiopentalbehandlung mittels gaschromatographischer Bestimmung der Konzentration im Serum

Zusammenfassung: Die Methode dient zur Bestimmung von Thiopental (und seines Metaboliten Pentobarbital) im Rahmen der Behandlung von Patienten mit Schädelhirntrauma mit hohen Dosen Thiopental.

$1 \mathrm{ml}$ Serum wird mit dem internen Standard und gesättigter Ammoniumsulfatlösung versetzt. Nach dem Mischen wird mit Chloroform extrahiert und die eingeengte organische Phase in den Gaschromatographen eingespritzt (stationäre Phase: SP 2510 DA). Präzision von Tag zu Tag: Variationskoeffizient 7,7\%; Wiederfindung: 97\%. Die Spezifität wurde geprüft durch Vergleich mit den Retentionsindices von über 80 Pharmaka. Eine Bestimmung dauert 1 Stunde.

\section{Introduction}

Barbiturate loading is of increasing importance in the treatment of neurosurgical patients $(1-3)$. One of the favourite barbiturates used for this purpose is thiopental. To be sure that the therapeutic range is quickly achieved and maintained in these patients, who often additionally suffer from hepatic or renal failure, drug monitoring is necessary. For the routine use of this therapy a method is needed that is practicable and can easily be run round the clock. Because of its specificity gaschromatography is preferred for the determination of thiopental. But among the gaschromatographic methods published so far some are rather sophisticated as they are primarily adapted to pharmacokinetic studies, where very low concentrations have to be measured. They involve time consuming sample preparation, derivatization, and special detectors (alkali flame ionization detector, electron capture detector) $(4-5)$ that are not available in many hospitals. Gaschromatographic methods using the widespread though less sensitive flame ionization need a time consuming sample preparation (6), derivatization (7) or column reconditioning after 6-12 samples in order to eliminate "dirt" peaks (\$). 
A method is presented that is appropriate for the routine monitoring of thiopental in neurosurgery because of its practicability (simple clean up, no derivatization, use of flame ionization detector, no temperature programming) and reliability.

\section{Materials and Methods}

Thiopental sodium [5-ethyl-5-(1'-methyl-butyl)-2-thio-barbiturate sodium]. $M_{r} 264.4$ (Byk Gulden Lomberg, Konstanz);

Cyclobarbital-Ca [5-ethyl-5-(cyclohex-1'-en-yl) barbiturate$\mathrm{Ca}_{1 / 2}$ ], $M_{\mathrm{r}} 255.3$ (Bayer, Leverkusen).

Disodium sulphate p.a., ammonium sulphate p.a., chloroform p.a. redistilled before use (Merck, Darmstadt).

Thiopental sodium is stabilised by the manufacturer by addition of $60 \mathrm{mg} \mathrm{Na} 2 \mathrm{CO}_{3}$ to $1 \mathrm{~g}$ of the drug; $1151 \mathrm{mg}$ of the mixture are dissolved in bidistilled water $(4.13 \mathrm{mmol} / \mathrm{h}$ thiopental) and 230.2 $\mathrm{mg} / \mathrm{l}$ in chloroform $(0.83 \mathrm{mmol} /$ thiopental $)$.

Cyclobarbital-Calcium is dissolved in bidistilled water (3.91 $\mathrm{mmol} / \mathrm{/}$ ); for gaschromatography the aqueous solution is extracted 3 times with chloroform, the organic phase is evaporated and made up with chloroform (final concentration $391 \mu \mathrm{mol} / \mathrm{l}$ ).

The solutions are stable for at least 4 weeks at $4{ }^{\circ} \mathrm{C}$.

Gaschromatography

Glass column: $1.8 \mathrm{~m}$ length; $2 \mathrm{~mm}$ internal diameter.

Stationary phase: GP $2 \%$ SP 2510 DA on Supelcoport 100/120 mesh (Supelco, Bellefonte, USA).

Gaschromatograph: Hewlett Packard 5880 A equipped with a flame ionization detector (Hewlett Packard, Frankfurt). Oven: $210^{\circ} \mathrm{C}$; inlet: $230^{\circ} \mathrm{C}$; detector: $240^{\circ} \mathrm{C}$. Carrier gas: Purged nitrogen $30 \mathrm{ml} / \mathrm{min}$.

\section{Procedure}

To $1 \mathrm{ml}$ serum $30 \mathrm{ul}$ aqueous cyclobarbital solution and $2 \mathrm{ml}$ saturated ammonium sulphate solution are added. The mixture is extracted with $5 \mathrm{ml}$ chloroform, centrifuged $10 \mathrm{~min}$ at $3000 \mathrm{~g}$ and the separated organic phase is dried by passage through small columns filled with $2 \mathrm{~g}$ sodium sulphate. This procedure is repeated two times and the combined eluates are evaporated. The residue is dissolved in chloroform and injected into the gaschromatograph. The thiopental concentration of the samples is computed by means of the regression line of the peak heights of the standard solution.

\section{Results}

\section{Precision in the series}

Serum was spiked with an aqueous solution of thiopental and $1 \mathrm{ml}$ aliquots were extracted as described. The coefficients of variation ranged from 4.2 to $5.9 \%$ (tab. 1).

\section{Precision from day to day}

Aliquots of spiked serum were frozen and thawed for analysis. The coefficient of variation was $7.7 \%$ for 10 single determinations (tab. 1).

\section{Accuracy}

Linearity was demonstrated from at least 41.3 to $371.3 \mu \mathrm{mol} / 1$ (fig. 1). The recovery without correction by the internal standard was $97 \%$ at a concentration of $41.3 \mu \mathrm{mol} / \mathrm{l}$.

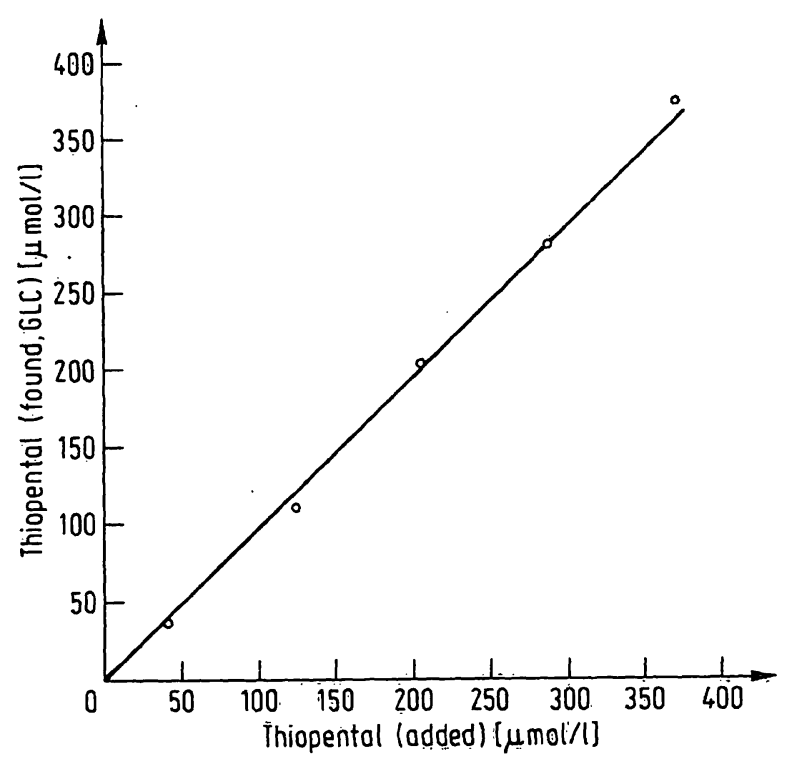

Fig. 1. Relationship between the concentration of thiopental added and thiopental as determined by gaschromatography.

\section{Specificity}

As a check for specificity the retention indices of the following drugs were determined according to $\mathrm{Ko}$ váts (9). A complete list will be published separately (10). The most relevant retention indices are given in brackets.

Acetylsalicylic acid

allobarbital

amikazin sulphate

aminophenazone

Tab. 1. Determination of thiopental: Precision

\begin{tabular}{llllll}
\hline & $\begin{array}{l}\text { Number of } \\
\text { determinations } \\
\mathrm{n}\end{array}$ & $\begin{array}{l}\text { Target value } \\
(\mu \mathrm{mol} / \mathrm{l})\end{array}$ & $\begin{array}{l}\text { Mean value } \\
\overline{\mathrm{x}} \\
(\mu \mathrm{mol} / \mathrm{l})\end{array}$ & $\begin{array}{l}\text { Deviation from } \\
\text { the target value } \\
(\%)\end{array}$ & $\begin{array}{l}\text { Coefficient } \\
\text { of variation } \\
(\%)\end{array}$ \\
\hline Precision in the series & 10 & 41.3 & 40.1 & -2.9 & 5.9 \\
Precision from day to day & 10 & 206.3 & 210.0 & +1.8 & 4.2 \\
\hline
\end{tabular}


amitriptyline

amobarbital

amphetamine sulphate

aprobarbital

barbital

benzydamine hydrochloride

brallobarbital

butalbital

carbamazepine

carbenicillin disodium

carbromal

chloramphenicol

chlordiazepoxide

chlorpromazine

chlorprothixene

clomethiazole ethanedisulphonate

codeine

crotarbital

cyclobarbital [3010]

cyclopal

desipramine hydrochloride

dextromoramide hydrogen tartrate

dextropropoxyphene hydrochloride

diazepam

2,2-diethylallylacetamide

diphenhydramine

doxepin hydrochloride [2715]

erythromycin

ethinamate

ethosuximide

flufenamic acid

glutethimide

guaiphenesin

haloperidol

heptabarbital

hexobarbital

imipramine hydrochloride

indomethacin

kanamycin sulphate

levorphanol tartrate

lidocaine hydrochloride

metamizol

methaqualone

methotrexate

.. methylphenobarbital

methyprylone

niflumic acid

nitrazepam

normethadone hydrochloride

oxazepam

oxyphenbutazone

paracetamol

pentobarbital [2665]

pethidine

phenacetin phenobarbital

phenprocoumon

phenylbutazone

phenytoin

primidone

probenecid

procainamide hydrochloride

promethazine hydrochloride

propallylonal

propylhexedrine

pyrithyldione

quinidine sulphate

quinine dihydrochloride

salicylic acid

sebutabarbital

secobarbital

sisomycin sulphate

streptomycin sulphate

sulphadimethoxine

sulphamethoxydiazine

sulphisoxazole

tetracycline hydrochloride

theophylline

thiopental [2730]

thioridazine hydrochloride

tobramycin

tolbutamide

triflupromazine hydrochloride

trimethoprim

vinylbital.

Of all these substances, only doxepine can interfere with the quantitative determination: It is extracted in high yield $(56 \%)$ by this procedure and has a retention index similar to thiopental. The therapeutic concentration of doxepine $(0.04-0.72 \mu \mathrm{mol} / \mathrm{l})$ (11) however is beyond the detectability of the method and a noticeable interference will only be encountered in lethal doxepine poisoning $(35.80 \mu \mathrm{mol} / \mathrm{l})$ (11). Endogenous serum constituents do not interfere with the determination (fig. 2).

As an estimate of detectability the precision of the method at low concentration was used. In serum spiked with $4.1 \mu \mathrm{mol} / /$ thiopental, a concentration of $5.2 \mu \mathrm{mol} / 1$ and a coefficient of variation of $22.8 \%$ were found $(n=8)$. In thiopental therapy of head injury 124 to $289 \mu \mathrm{mol} / \mathrm{l}$ is considered as the (preliminary) therapeutic range (12) needed to achieve a burst suppression electroencephalogram; this is based on determinations of multiple samples taken from each of 15 patients during the course of their disease. The determination of a sample takes 1 hour after receipt by the laboratory. 


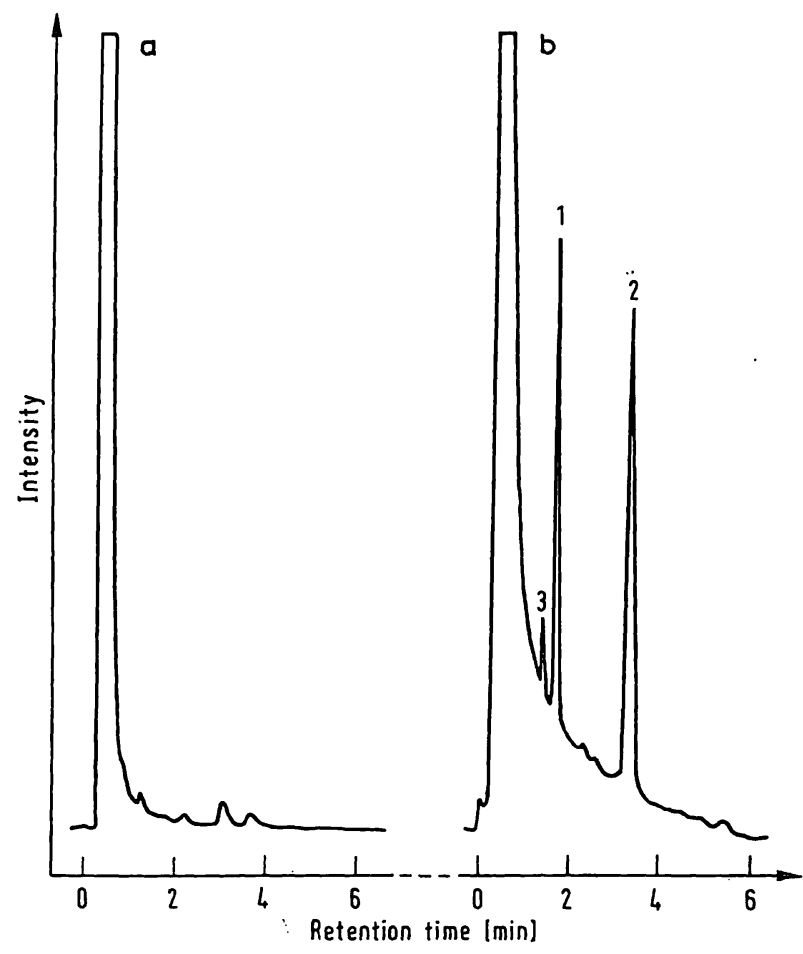

Fig. 2. a) Gaschromatogram of an extract of drug-free serum

b) Gaschromatogram of serum taken from a patient treated with thiopental

1 Thiopental $(99.1 \mu \mathrm{mol} / \mathrm{/})$

2 Cyclobarbital (internal standard)

3 Pentobarbital $(19.3 \mu \mathrm{mol} / \mathrm{l})$

\section{Discussion}

As shown above thiopental can be determined by this method without derivatization. Gaschromatography can therefore be run by use, of an autosampler if many samples are to be analysed e.g. in pharmacokinetic studies, and a nitrogen sensitive detector can be used without precautions as well as a flame ionization detector. Alkylating procedures often give products that are unstable and must be injected immediately after addition of the reagent; otherwise the nitrogen containing derivatizing reagent leads to an overflow and to a contamination of the nitrogen flame ionization detector. It is a further advantage that pentobarbital as a hypnotic active metabolite of thiopental can be determined simultaneously. Especially in patients with reduced clearance rates the measurement of both thiopental and pentobarbital serum concentrations may prevent overdosage. Thiopental monitoring is a valuable method in high dose barbiturate therapy in addition to the EEG. Only by determination of the thiopental concentration one can decide if an isoelectric EEG is due to overdosage or to an irreparable breakdown of brain functions.

\section{References}

1. Astrup, J. (1980) Scand. J. Clin. Lab. Invest. 40, 201-203.

2. Steen, P. A. (1980) Scand. J. Clin. Lab. Invest. 40, 205-207.

3. Renck, H. (1980) Scand. J. Clin. Lab. Invest. 40, 209-210.

4. Smith, R. H., MacDonald, J. A., Thompson, D. S. \& Flacke, W. E. (1977) Clin. Chem. 23, 1306-1309.

5. Jung, D., Mayersohn, M. \& Perrier, D. (1981) Clin. Chem. 27, 113-115.

6. Van Hamme, M.J. \& Ghoncim, M. M. (1978) Br. J. Anaesth. 50, 143-145.

7. Becker, K. E. jr. (1976) Anesthesiology 45, 656-660.

8. Grieve, G. A. \& Hatch, D. V. M. (1972) Am. J. Vet. Res. 33, 195-201.

9. Kováts, E. (1958), Helv. Chim. Acta 41, 1915-1932.

10. Külpmann, W. R. \& Fitzlaff, R. in preparation.

11. Pentz, R., Strubelt, O. \& Gehlhoff, C. (1979) Dtsch. Ärztebl. 76, 2815-2820.

12. Dietz, H., Külpmann, W. R., Seidel, H. P. \& Spring, A. (1981) Neurochirurgia (Suppl.) 1657 th International Congress of Neurological Surgery München, 12.-18. Jụly.

Prof. Dr. W. R. Külpmann

Institut für Klinische Chemie

Medizinische Hochschule Hannover

Karl-Wiechert-Allee 9

D-3000 Hannover 61 